\title{
COVID-19 in Gastroenterology Departments: The Impact of the First Wave
}

\author{
Tiago Leal $^{\text {a }}$ Margarida Gonçalves $^{\text {a }}$ Irina Mocanu ${ }^{b}$ Rita Carvalho ${ }^{c}$

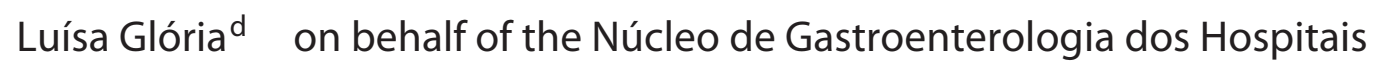 \\ Distritais
}

\begin{abstract}
a Department of Gastroenterology, Hospital de Braga, Braga, Portugal; ${ }^{b}$ Department of Gastroenterology, Hospital Garcia de Orta, Almada, Portugal; ' CDepartment of Gastroenterology, Hospital Professor Doutor Fernando Fonseca, Amadora, Portugal; ${ }^{d}$ Department of Gastroenterology, Hospital Beatriz Ângelo, Loures, Portugal
\end{abstract}

\section{Keywords}

COVID-19 · Pandemic $\cdot$ Telehealth $\cdot$ Endoscopy $\cdot$ Fellowship

\section{Abstract}

Introduction: Coronavirus disease 2019 (COVID-19) is a global pandemic that has severely affected health care systems around the world. During the emergency state declared in Portugal in the months of March and April 2020, there was a severe reduction in medical activity in order to reduce the pressure on health systems. This study aimed to assess the impact of COVID-19 in gastroenterology departments across Portugal and the strategies developed to overcome this challenge. Methods: This was a cross-sectional study based on an online survey. A detailed questionnaire concerning different aspects of gastroenterology department activity was sent via e-mail to the heads of gastroenterology departments of Portuguese District Hospitals (Núcleo de Gastroenterologia dos Hospitais Distritais). Two periods were assessed, i.e., the emergency state and the recovery period between May and September. The responses were collected between September and October 2020. Results: A total of 21 hospitals were enrolled ( $80.8 \%$ re- sponse rate). Twenty-eight percent of the responders reported healthcare professionals from their unit infected with $\mathrm{CO}$ VID-19. At least 1 member (mostly fellows) of the department was deployed to another workplace in $66.7 \%$ of the hospitals. During the emergency state, $47.6 \%$ of the hospitals only performed urgent/emergent endoscopic procedures. In $38.5 \%$ of the hospitals the need to ration personal protective equipment led to the suspension of endoscopic training. Regarding the recovery period, nonurgent procedures were restarted in almost all of the centers. The same was reported for the colorectal cancer screening program. Remarkably, $81 \%$ of the responders confirmed that they had postponed procedures at patients' request for "fear of getting infected." Remote consultation was maintained in $81 \%$ of the hospitals. Globally, the fellows had resumed their training. Discussion/Conclusion: This study provides a snapshot of the impact and consequences of the first wave of the COVID-19 pandemic across Portuguese hospitals. It is important to understand how the gastroenterology world dealt with the first impact of COVID-19 and what strategies were implemented in order to better prepare for what might follow.

(c) 2021 Sociedade Portuguesa de Gastrenterologia Published by S. Karger AG, Basel karger@karger.com www.karger.com/pjg

Karger $\stackrel{\text { ' }}{5}$

BOPEN ACCESS
(C) 2021 Sociedade Portuguesa de Gastrenterologia Published by S. Karger AG, Basel

This is an Open Access article licensed under the Creative Commons Attribution-NonCommercial-4.0 International License (CC BY-NC) (http://www.karger.com/Services/OpenAccessLicense), applicable to the online version of the article only. Usage and distribution for commercial purposes requires written permission.
Correspondence to:

Tiago Leal, tiago.afleal@gmail.com 


\section{COVID-19 nos Serviços de Gastroenterologia: o impacto da $1^{\text {a }}$ vaga}

\section{Palavras Chave}

COVID-19. Pandemia $\cdot$ Telemedicina $\cdot$ Endoscopia $\cdot$ Internato

\section{Resumo}

Introdução: A doença por coronavirus 19 (COVID-19) é uma pandemia global que afetou gravemente os serviços de saúde em todo o mundo. Durante o estado de emergência declarado em Portugal nos meses de Março e Abril de 2020, verificou-se uma redução importante na atividade médica. Este estudo teve como objetivo avaliar o impacto da COVID-19 nos Serviços de Gastroenterologia portugueses e as estratégias implementadas para fazer face a este desafio. Métodos: Tratou-se de um estudo transversal baseado num inquérito online. Um questionário pormenorizado acerca de diferentes aspetos da atividade dum Serviço de Gastroenterologia foi enviado por email para os Diretores de Serviço de Gastroenterologia dos Hospitais Distritais. Foram avaliados dois períodos: o estado de emergência e o período de recuperação entre maio e setembro. Foram registadas as respostas entre setembro e outubro 2020. Resultados: Responderam 21 Hospitais (taxa de resposta: 80,8\%). Vinte e oito porcento dos inquiridos tiveram profissionais da sua unidade infectados com COVID-19. Pelo menos um elemento foi mobilizado para outro local de trabalho em $66,7 \%$ dos hospitais, maioritariamente internos de formação específica de Gastroenterologia. Durante o estado de emergência, $47,6 \%$ dos Hospitais só realizaram endoscopias urgentes/emergentes. Em 38,5\%, a necessidade de racionamento de equipamento de proteção individual levou à suspensão do treino em endoscopia. Relativamente ao período de recuperação, os procedimentos não urgentes foram retomados na maioria dos centros. O mesmo se verificou para o programa de rastreio do cancro colorectal. Salienta-se que $81 \%$ dos inquiridos confirmaram que adiaram exames a pedido dos doentes por "medo de ficarem infetados". Mantiveram-se consultas nãopresenciais em $81 \%$ dos Hospitais. De modo geral, as atividades de formação dos internos foram progressivamente retomadas. Discussão/Conclusão: Este estudo oferece o retrato do impactoe consequências da primeira vaga da pandemia nos Hospitais portugueses. É importante compreender como os Serviços de Gastrenterologia nacionais lidaram com o primeiro impacto da COVID-19 e que estratégias foram implementadas de forma a melhor preparar o que se segue.

(c) 2021 Sociedade Portuguesa de Gastrenterologia Publicado por S. Karger AG, Basel

\section{Introduction}

Coronavirus disease 2019 (COVID-19) is a public health emergency caused by the severe acute respiratory syndrome coronavirus 2 (SARS-CoV-2) virus [1] that was first detected in Wuhan, China, in December 2019 and quickly spread to different countries, being classified as a pandemic by the World Health Organization in March 2020.

In Portugal the first cases were confirmed on March 3 and after that the number of infected people increased steadily, leading to the declaration of a state of emergency on March 18 and a consecutive lockdown of society until May 2.

COVID-19 has affected clinical practice in several ways and disrupted health care delivery systems around the world, including gastroenterology care and gastroenterology training. A Harvard study showed a $60 \%$ decline in the number of visits to ambulatory practices since early April 2020 [2]. To prevent the transmission of COVID-19 within endoscopy units, infection control measures were and are being established. These measures are intended to reduce the risk of spread of infection from possible COVID-19 patients, reduce the risk of cross-infection, and preserve the use of personal protective equipment [1]. Resorting to telemedicine for patient management, restricting nonessential procedures, and following strict protective strategies seem to be the key to help sail through these difficult times [3]. However, despite the benefits in terms of control of the pandemic, the prolonged suspension of everyday gastrointestinal practice will result in many gastrointestinal conditions that were once allowed to wait now requiring more urgent attention.

In this line of thought, the authors consider it is essential to investigate how the pandemic has affected Portuguese hospitals. Thus, this study aimed to assess the impact of COVID-19 in gastroenterology departments across Portugal and the strategies developed to overcome these challenges.

\section{Materials and Methods}

This is a cross-sectional study based on an online survey. A detailed questionnaire concerning different aspects of gastroenterology department activity was developed. The questions regarded numerous areas, i.e., staff planning, endoscopy unit, outpatient clinic, gastroenterology ward, and fellows in training. Two different periods were assessed, i.e., the first peak (during the emergency state) and the recovery period (from May to September 2020). The online survey, using the Google Forms ${ }^{\circledR}$ platform, was sent via e-mail to the heads of gastroenterology departments of Portuguese District Hospitals $(n=26)$. The answers were collected during 2
Leal et al. 


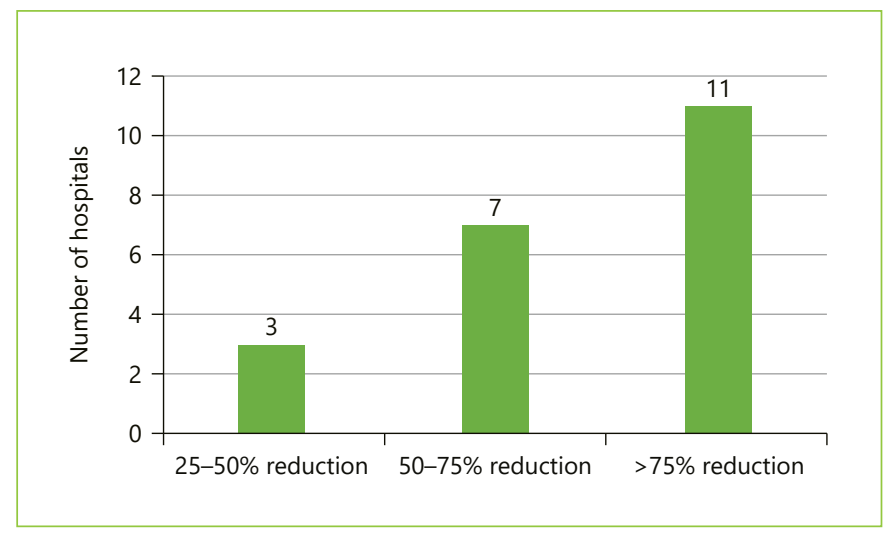

Fig. 1. Reduction of planned endoscopy productivity in the state of emergency compared to the prepandemic period.

months (September and October). A reminder was sent via e-mail during the month of October. Those who had not responded by October 31, 2020, were considered nonresponders.

The Portuguese District Hospital Gastroenterology Departments consist of medium-sized to large facilities, secondary or tertiary centers, with a variable staff size. They all perform urgent and elective endoscopic procedures and outpatient consultations, as well as inpatient activity. Several departments provide gastroenterology training, with different numbers of fellows.

\section{Statistical Analysis}

For the statistical analysis a Microsoft Office Excel ${ }^{\circledR}$ spreadsheet was used, since only a descriptive analysis was performed. Data were presented as frequencies for categorical variables and medians (IQR) for continuous variables.

\section{Results}

During the study period, a total of 21 heads of gastroenterology departments filled out the questionnaire, which represents an $80.8 \%$ response rate. There were 4 hospitals from the northern region of Portugal, 8 from the center, 5 from the Lisbon metropolitan area, 1 from the south, and 3 from Madeira and Azores. These departments had a median of $6(\mathrm{IQR}=4)$ senior gastroenterologists and 13 had fellows in training (median 3 fellows/ department, IQR $=1.75$ ). All of the participating hospitals had patients hospitalized with COVID-19.

\section{First Peak}

COVID-19 in Healthcare Workers

A total of $28.6 \%(n=6)$ of the responders reported that healthcare professionals from their unit were infected with COVID-19, with the nursing staff being the most af-

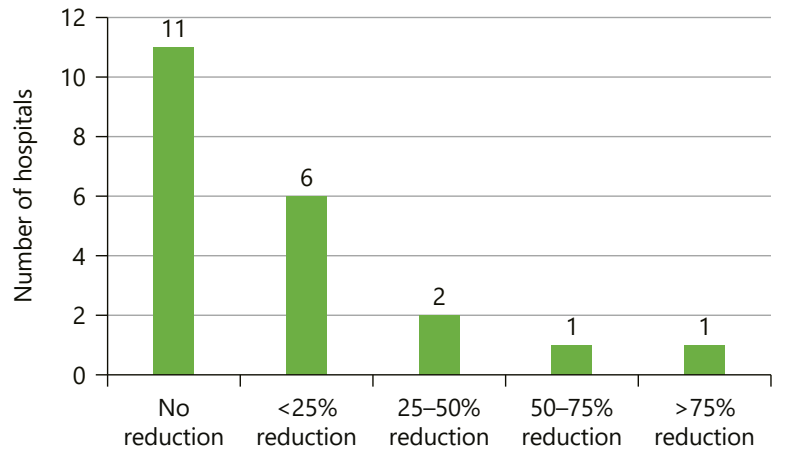

Fig. 2. Reduction of urgent endoscopy productivity in the state of emergency compared to the prepandemic period.

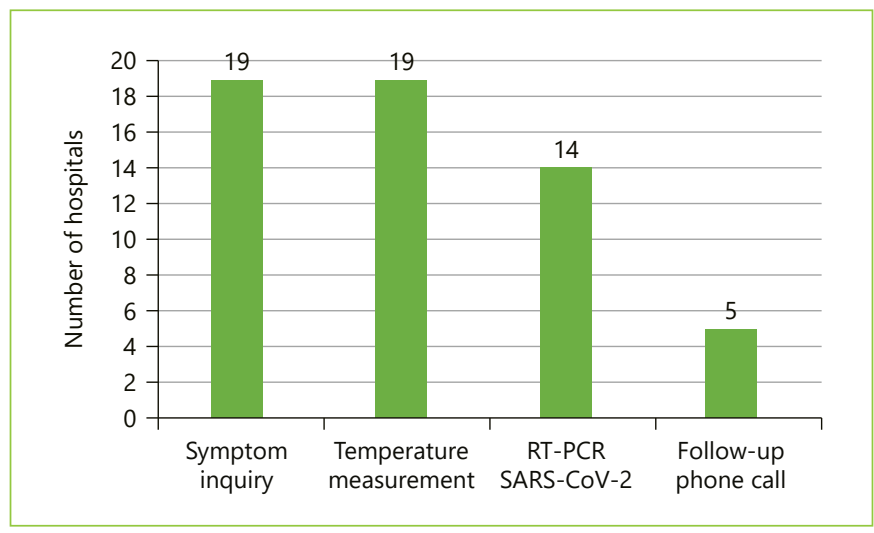

Fig. 3. COVID-19 screening strategies in patients undergoing endoscopy.

fected $(n=5)$, followed by healthcare assistants $(n=3)$ and finally medical doctors $(n=1)$. Most units had only 1 infected individual, but one department had 4 and another had 7 infected healthcare professionals.

\section{General Planning}

The pandemic had a significant impact on almost all gastroenterology departments. In terms of organization of the work schedule, $86 \%$ created rotating teams with different schedules and 14\% maintained the usual schedule but defined strictly separate work places. In $66.7 \%$ $(n=14)$ of the departments it was necessary to deploy members of the department to another non-gastroenterology-related activity. The most frequently deployed members were fellows $(n=9)$, and they were deployed to the COVID-19 ward $(n=9)$ or the general emergency de- 


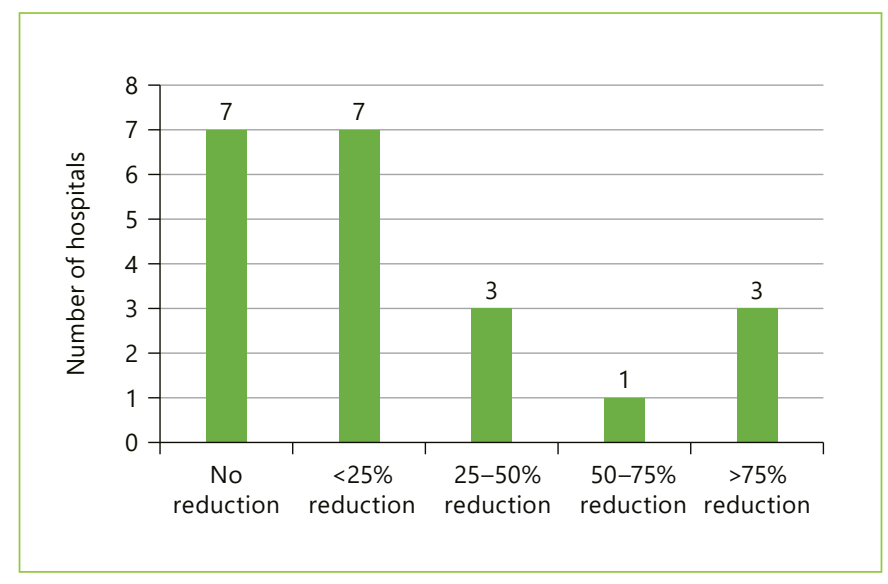

Fig. 4. Reduction of outpatient consultations during the state of emergency compared to the prepandemic period.

partment $(n=9)$. Regarding telework, in 9 hospitals doctors already had remote access from their home before the pandemic and 7 were provided access during this period. The most frequent activities performed from home were medical appointments and meetings.

\section{Endoscopy Unit}

The location of the endoscopy unit had to be changed in $5(23.8 \%)$ hospitals. Only $19.0 \%(n=4)$ of the departments have negative pressure rooms, but in $58.9 \%$ $(n=10)$ of the remaining departments a room with appropriate conditions for performing procedures in high risk patients was provided. Planned endoscopy shifts had to be cancelled in $76.2 \%(n=16)$ of the hospitals, mostly due to service rearrangement $(n=9)$ and shortness of staff $(n=4)$. In fact, during the emergency state, $47.6 \%(n=10)$ of the hospitals only performed urgent/emergent endoscopic procedures, which was in keeping with national guidelines. Of the 15 hospitals enrolled in a colorectal cancer screening program, only $1(6.7 \%)$ did not suspend it. The reduction in planned and urgent endoscopic activity is depicted in Figures 1 and 2 .

Concerning preendoscopic screening of COVID-19, the most frequent measures were symptom inquiry and temperature measurement, as can be seen in Figure 3 . The pandemic also took a toll on anesthesiology collaborations, as 9 (42.9\%) departments failed to keep endoscopy shifts with anesthesiologist sedation. Finally, 4 responders confirmed that there was a shortage/rationing of personal protective equipment in their department.

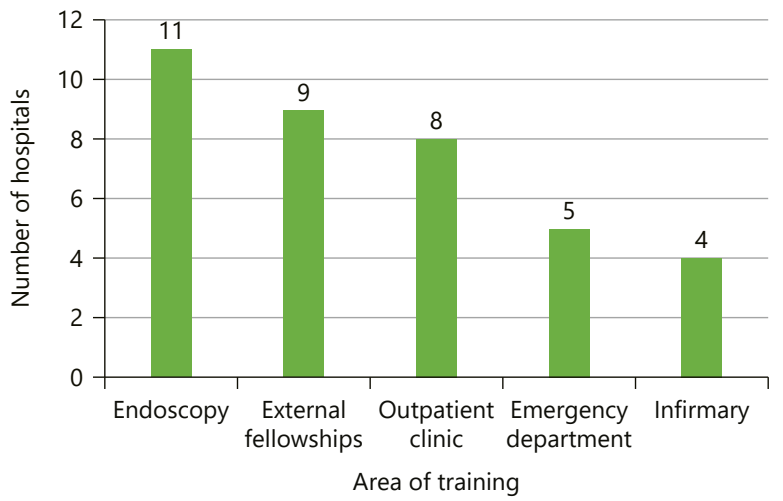

Fig. 5. Areas of gastroenterology training affected by the pandemic.

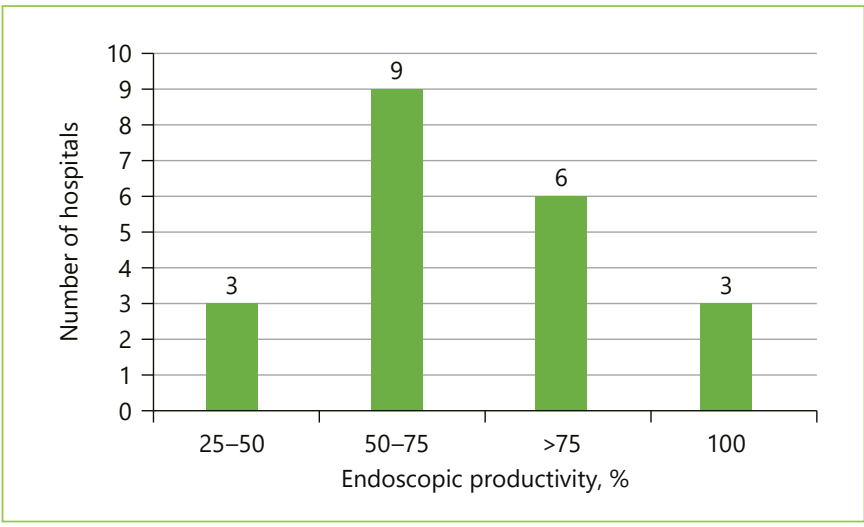

Fig. 6. Endoscopic productivity in the recovery period compared to the prepandemic period.

\section{Outpatient Clinic and Gastroenterology Ward}

The reduction in medical appointments was rather variable (Fig. 4). Face-to-face consultations took place in $71.4 \%(n=15)$ of the hospitals, mostly in specific situations, such as first appointments. On the other hand, all of the hospitals performed remote consultations, i.e., 3 via video calls and 10 via phone calls from home.

In terms of outpatient treatments, the location of the day hospital had to be changed in $38.1 \%(n=8)$ of the hospitals. However, planned administration of biological therapy for inflammatory bowel disease was postponed or canceled in only 3 hospitals and large volume paracentesis for refractory ascites in only 1.

Finally, due to hospital reorganization, 6 departments saw their gastroenterology ward reduced while in 1 it was increased and in 5 its location had to be changed. 
Fellows in Training

Of the 13 hospitals that had fellows in training, the majority of the responders $(n=11)$ considered the training of their fellows to have been significantly altered, with only 1 saying it had been mildly altered and 1 replying that there had been no impact on gastroenterology training. Figure 5 shows the different areas in which the heads of gastroenterology departments felt their fellows had been affected. In $38.5 \%(n=5)$ of the departments the need to ration personal protective equipment led to the suspension of endoscopic training.

\section{Recovery Period}

Staff Planning

Concerning the recovery period, at the time of answering the survey, $14.3 \%(n=3)$ of the hospitals did not have the complete medical staff back in service, $38.1 \%(n=8)$ kept working in rotating teams in different schedules, and $28.6 \%(n=6)$ had some kind of remote activity. Healthcare professionals were screened for COVID-19 in 57.1\% $(n=12)$ of the hospitals, mostly by temperature measurement and symptom screening.

\section{Endoscopy Unit}

The overall endoscopic productivity in comparison to the period before the pandemic is presented in Figure 6; it was under $75 \%$ in more than half the hospitals $(n=12)$. In general, nonurgent/nonemergent procedures (95.2\%) and endoscopic shifts with anesthesiologist sedation (100\%) were resumed. The colorectal cancer screening program was restarted in 14 (93.3\%) hospitals. In 6 hospitals a plan for overtime endoscopy work was developed in order to reduce the waiting list. The measures of preendoscopic screening remained largely the same. It is important to stress that $81 \%(n=17)$ of the responders confirmed that they had postponed procedures at patients' request for "fear of getting infected."

Outpatient Clinic and Gastroenterology Ward

On the whole, medical appointments were resumed, with $19(90.5 \%)$ hospitals achieving $75-100 \%$ of the productivity from before the pandemic. Remote consultations were maintained in 17 (81\%) hospitals and ranged from $<25$ to $>75 \%$ of all consultations. These hospitals were planning to keep some kind of remote consultation in the near future.

Regarding inpatients, only 1 hospital had not resumed normal activity. Of those who changed location, only 1 (12.5\%) had returned to the original place. Likewise, regarding the day hospital, most (85.7\%) had returned to
$>75 \%$ normal productivity, even though only 3 (37.5\%) had returned to the usual location.

Fellows in Training

There were only 12 responses to this section from the 13 departments that had fellows. Most areas of gastroenterology training were restarted (outpatient clinic, 91.7\%; endoscopy, 91.7\%; inpatient care, 100\%; and emergency unit, $100 \%)$. However, external fellowships, seeking to further expand the training of a specific area in dedicated centers, were severely compromised, since only $33.3 \%$ had been able to resume/reschedule.

\section{Discussion/Conclusion}

This study provides a detailed picture of the impact and consequences of the first wave of the COVID-19 pandemic across Portuguese hospitals.

In the beginning, the pandemic took the whole world by surprise, and the health services were no exception. In one of the earliest reports from Wuhan, around 29\% of positive cases were healthcare workers [4]. Therefore, the frequency of infected professionals in this study is not surprising, as it has been described that healthcare workers have a 3-fold risk of being infected or hospitalized with COVID-19 in comparison to the general population $[5,6]$.

Gastroenterologists are at an increased risk for COVID-19 considering the potential of airborne transmission in upper gastrointestinal endoscopy. In fact, endoscopic practice has suffered tremendously, especially in the most severely hit areas. Reports from New York mention an $80-90 \%$ procedural volume reduction [7]. In addition to the health hazard, human and logistics resources reallocation in the midst of the pandemic led to this endoscopic "lockdown." Indeed, both international and national recommendations $[8,9]$ advised postponement of elective, nonurgent procedures in the beginning of the pandemic due to a high risk of infection for both patients and healthcare professionals. Consequently, almost half of the study's responders only performed emergent/urgent endoscopies during the emergency state. These necessary restrictions imposed by the new coronavirus are expected to have dire consequences. The reduction in endoscopically detected cancers was reported to be around $58 \%$ [10]. Moreover, in a predictive model to estimate the impact of delayed diagnosis on cancer survival, a $15 \%$ increase in the 5-year mortality rate was calculated for colorectal cancer and a $6 \%$ increase was found for esoph- 
ageal cancer [11]. Analysis of the recovery period revealed that the majority of hospitals were yet able to achieve a normal procedure volume. On the other hand, almost all of the centers participating in a colorectal cancer screening program had resumed this activity. This delay is likewise expected to have consequences, as it has been determined that performing colonoscopy more than 6 months after a fecal immunochemical test is associated with an increased risk of colorectal cancer diagnosis and in a more advanced stage [12]. Finally, it is important to emphasize that a gastroenterologist was infected only in 1 hospital. This could indicate that endoscopic activity is safe when all of the necessary precautions are taken.

Although it is recommended to screen patients for symptoms and high-risk contacts before endoscopy [13], this was not performed in all hospitals. Remarkably, the large majority of responders confirmed that we are limited not only by endoscopy constraints but also by patients' concerns, since requests to postpone procedures out of fear are a reality. Even though the risk of getting infected is not zero, all of the efforts put into planning and preventive strategies will drive it down to the very minimum.

Telehealth is defined as the provision of healthcare remotely by means of a variety of telecommunication tools, including telephones, smartphones, and mobile wireless devices, with or without a video connection [14]. Since the start of the pandemic, we have witnessed a remarkable increase in this model of care [15]. It proved to be a valuable tool to keep healthcare providers in contact with their patients while avoiding the risk of infection. Recent studies assessing patients' perspectives have reported high acceptability and satisfaction rates for this model $[16,17]$. However, it might not be appropriate for certain patients and specific situations, which require individual adaptations. Not all elderly patients will adjust to this approach due to sensory or cognitive impediments [18], and remote consultation cannot be an option when physical examination or direct patient contact is required. Thus, $71 \%$ of hospitals maintained some face-to-face consultations even in the emergency state. Nevertheless, there is a general feeling, which is mirrored in our study, that telemedicine will persist in the future and have an important role in gastrointestinal practice [19].

Our study confirms the important impact of COVID-19 in gastroenterology training, i.e., endoscopic activity seems to have been widely affected in the beginning during the emergency state. Fortunately, it has been resumed, even though necessary measures to en- sure safety conditions, such as different patient pathways and increased disinfection between patients, will surely reduce the usual procedure volume and prevent the full normalization of endoscopic training. There is general concern regarding gastroenterology training around the world. In a large international survey, comprising more than 700 trainees, $93.8 \%$ of respondents reported a reduction in endoscopy case volume [20]. In a US study, $64 \%$ of fellows felt that endoscopic restrictions will impact endoscopic skills at the end of training [21]. Alas, external fellowships at different institutions, which are a much expected and valuable experience, were enduringly affected by the pandemic. Lastly, praise is due to the gastroenterology fellows who, as stated in our paper, were frequently deployed to the front line, putting aside their training to contribute to dealing with the public health threat.

This study has a few limitations. Firstly, only district hospitals were surveyed, excluding larger hospitals from Lisbon, Porto, or Coimbra, which may have had different experiences due to their size and characteristics. Nonetheless, the majority of national hospitals and the majority of gastroenterologists is represented in the study sample. Additionally, only the answers of the department head were considered, and these may be different from individual perspectives. On the other hand, the former may constitute a more comprehensive view, as this is the person who oversees all of the activity.

In conclusion, the current pandemic significantly impaired gastroenterology practice and it will take time to return to normal. With the numbers of patients infected with COVID-19 are globally increasing, it is important to understand how the gastroenterology world dealt with the first impact of COVID-19 and what strategies were implemented to face the continuously changing knowledge of this disease in order to better prepare for the waves that might follow.

\section{Statement of Ethics}

Consent for participation in this study was inferred from voluntary completion of the survey questionnaire. The authors declare that the procedures followed were in accordance with the World Medical Association Declaration of Helsinki.

\section{Conflict of Interest Statement}

The authors have no conflict of interests to declare. 
Funding Sources

There are no funding sources to declare.

\section{Author Contributions}

T.L. was responsible for the design of this study, data analysis, and drafting of this paper. M.G. was responsible for data analysis and helped to draft this paper. I.M., R.C., and L.G. were responsible for the design of this study, data collection and interpretation, and critical revision of this work for important intellectual content. All of the authors approved the final version for publication and agreed to be accountable for all aspects of this work.

\section{References}

1 Aguila EJ, Cua IH, Dumagpi JE, Francisco CP, Raymundo NT, Sy-Janairo ML, et al. COVID-19 and its effects on the digestive system and endoscopy practice. JGH Open. 2020 May;4(3):324-31.

2 Mehrota A, Chernew M, Linetsky D, et al. The impact of the COVID-19 pandemic on outpatient visits: a rebound emerges. New York: Commonwealth Fund; 2020.

3 Dhar J, Samanta J, Kochhar R. Corona Virus Disease-19 pandemic: the gastroenterologists' perspective. Indian J Gastroenterol. 2020 Jun;39(3):220-31.

4 Wang D, Hu B, Hu C, Zhu F, Liu X, Zhang J, et al. Clinical characteristics of 138 hospitalized patients with 2019 novel coronavirus-infected pneumonia in Wuhan, China. JAMA. 2020 Mar;323(11):1061-9.

5 Nguyen LH, Drew DA, Graham MS, Joshi AD, Guo CG, Ma W, et al.; Coronavirus Pandemic Epidemiology Consortium. Risk of COVID-19 among front-line health-care workers and the general community: a prospective cohort study. Lancet Public Health. 2020 Sep;5(9):e475-83.

6 Shah AS, Wood R, Gribben C, Caldwell D, Bishop J, Weir A, et al. Risk of hospital admission with coronavirus disease 2019 in healthcare workers and their households: nationwide linkage cohort study. BMJ. 2020 Oct; 371:m3582.

7 Sethi A, Swaminath A, Latorre M, Behin DS, Jodorkovsky D, Calo D, et al.; New York Society for Gastrointestinal Endoscopy. Donning a new approach to the practice of gastroenterology: perspectives from the COVID-19 pandemic epicenter. Clin Gastroenterol Hepatol. 2020 Jul;18(8):1673-81.
8 Gralnek IM, Hassan C, Beilenhoff U, Antonelli G, Ebigbo A, Pellisè M, et al. ESGE and ESGENA position statement on gastrointestinal endoscopy and the COVID-19 pandemic. Endoscopy. 2020 Jun;52(6):483-90.

9 Sociedade Portuguesa de Endoscopia Digestiva. COVID-19 e endoscopia digestiva: $3^{\circ} \mathrm{Co}-$ municado. Available from: https://www.sped. pt/images/2020/Covid-19/SPED_e_COVIDcomunicado_3.pdf.

10 Rutter MD, Brookes M, Lee TJ, Rogers P, Sharp L. Impact of the COVID-19 pandemic on UK endoscopic activity and cancer detection: a national endoscopy database analysis. Gut. 2021 Mar;70(3):537-43.

11 Maringe C, Spicer J, Morris M, Purushotham A, Nolte E, Sullivan R, et al. The impact of the COVID-19 pandemic on cancer deaths due to delays in diagnosis in England, UK: a national, population-based, modelling study. Lancet Oncol. 2020 Aug;21(8):1023-34.

12 Lee YC, Fann JC, Chiang TH, Chuang SL, Chen SL, Chiu HM, et al. Time to colonoscopy and risk of colorectal cancer in patients with positive results from fecal immunochemical tests. Clin Gastroenterol Hepatol. 2019 Jun;17(7):1332-40.e3.

13 Filho EC, Castro R, Fernandes FF, Pereira G, Perrazo H. Gastrointestinal endoscopy during COVID-19 pandemic: an updated review of guidelines and statements from international and national societies. 2020. Available from: https://www.asge.org/home/advancededucation-training/covid-19-asge-updatesformembers.

14 Dorsey ER, Topol EJ. State of telehealth. N Engl J Med. 2016 Jul;375(2):154-61.
15 Tang Z, Dubois S, Soon C, Agrawal D. A model for the pandemic and beyond: Telemedicine for all outpatient gastroenterology referrals reduces unnecessary clinic visits. J Telemed Telecare. 2020 Sep 20: $1357633 X 20957224$.

16 Dobrusin A, Hawa F, Gladshteyn M, Corsello P, Harlen K, Walsh CX, et al. Gastroenterologists and patients report high satisfaction rates with telehealth services during the novel coronavirus 2019 pandemic. Clin Gastroenterol Hepatol. 2020 Oct;18(11):2393-7.e2.

17 Gomes C, Pinho R, Ponte A, et al. Patient's perspective on the implementation of measures to contain the SARS-CoV-2 pandemic in a Portuguese gastroenterology department. Eur J Gastroenterol Hepatol. 2021 Apr;33(4): 527-32.

18 Batsis JA, DiMilia PR, Seo LM, Fortuna KL, Kennedy MA, Blunt HB, et al. Effectiveness of ambulatory telemedicine care in older adults: a systematic review. J Am Geriatr Soc. 2019 Aug;67(8):1737-49.

19 Keihanian T, Sharma P, Goyal J, Sussman DA, Girotra M. Telehealth utilization in gastroenterology clinics amid the COVID-19 pandemic: impact on clinical practice and gastroenterology training. Gastroenterology. 2020 Oct;159(4):1598-601.

20 Pawlak KM, Kral J, Khan R, Amin S, Bilal M, Lui RN, et al. Impact of COVID-19 on endoscopy trainees: an international survey. Gastrointest Endosc. 2020 Oct;92(4):925-35.

21 Clarke K, Bilal M, Sánchez-Luna SA, Dalessio S, Maranki JL, Siddique SM. Impact of COVID-19 pandemic on training: global perceptions of gastroenterology and hepatology fellows in the USA. Dig Dis Sci. 2020 Oct 19;1-5. 